\title{
Evaluation and Application of Overvoltage into Communication Equipment due to Potential Rise at Earthing Terminal of Distribution Line Induced by Lightning Surge
}

\author{
Katsuji Ito Member (Yokohama National University) \\ Yasuo Hirose Member (Yokohama National University)
}

Keywords : overvoltage, communication equipment, potential rise, earthing terminal, surge current, discharge current, distribution arrester

Distribution system supplies energy to communication system with pole-mounted compact source equipment.

Harmful breakdown troubles by surge currents due to thunderstorm lightnings often occur in communication system equipment like CATV systems installed together with power distribution systems. This is mainly because over voltages to the equipment due to lightnings, which are usually taken into account for power equipment when the power distribution system is designed, have not been known precisely for communication system, and hence, proper protection methods have not been taken.

This paper describes a quantitative evaluation method of these overvoltages caused by lightning surge currents and especially those due to discharge of power distribution system arresters, and possible protection means of the communication equipment against them.

The origin and natures of the surge currents of distribution system, their invading route into power and communication system, and transmission behaviors of surge current in power system and communication system are studied, and then, the main circuit components affecting overvoltages such as earth impedance, low voltage transmission line, communication power transformer, and coaxial cable for signal and power transmission are also studied at the point of surge current flow.

Then, circuit model of power system and communication system united in a string is proposed for surge current, and transient analyses are performed to evaluate the overvoltages. The analyses have revealed the mechanism of the overvoltages of all equipments tied in the same earthing of the communication system, and that harmuful and appreciable overvoltages are given to the communication equipments.

Application of the obtained analysis results in the difference of the field fault data of communication equipment, and possible protection methods of them are also discussed, and hence, the usefulness of the present method of evaluating overvoltages is shown. 


\title{
サージ電流による配電線の接地点電位上昇に伴う 通信機器への過電圧の評価と応用
}

\author{
正 員 伊東 勝二* 正 員 廣瀬 靖雄*
}

\begin{abstract}
Evaluation and Application of Overvoltage into Communication Equipment Due to Potential Rise at Earthing Terminal of Distribution Line Induced by Lightning Surge

Katsuji Ito, Member, Yasuo Hirose, Member
\end{abstract}

\begin{abstract}
Overvoltage induced by surge currents due to thunderstorm lightnings causes harmful breakdown troubles of CATV communication equipment installed in and with power distribution systems. In this paper, the origin and natures of surge currents, their invading route into the system, and the system components such as earth impedances affecting over voltages are studied. Transient analyses are then performed using an equivalent circuit to evaluate over voltages. Application of the obtained results to the field fault data of communication equipment and possible protection method of them are discussed.
\end{abstract}

キーワード : 通信機器の過電圧, 通信用電源, 接地点電位の上昇, 配電用避雷器, 放電電流, サージ電流

Keywords : overvoltage, communication equipment, potential rise, earthing terminal, surge current, discharge current, distribution arrester

\section{1. はじめに}

架空配電線から電柱に設置した通信用電源装置に直接受 電する CATV 設備などの場合, 雷害関係の故障がなかなか 減らなかった(1)。関東一円に亘る 10 万軒を超える CATV の 顧客に配信する通信設備の故障データを筆者の一人がかつ て調べた。これらのデータの中で，作業など人による原因 の故障を除くと, 故障データのうち, 明らかに雷害と考え られるもの，その可能性があると保守員が判断したものが 多かった。通信装置にはサージ対策として装置内の相導体 間などにサージ保護装置などを付けてはいるが，サージに より生ずる過電圧が明らかではないためその効果には不明 な点が多く, この対策が機器が使用されるシステムの規模, 場所, 分岐の有無などによる使用状況を何処まで考慮した ものか明確では無かった。

本論文では, 配電系では問題とされてこなかった避雷器 の放電電流・続流の影響も考慮し，電柱に併設した設備か ら電力供給を受ける通信用機器に雷サージが原因でかかる 過電圧の定量的評価を行い保護方針を得ることを目的とし て検討を行うことにした。この場合，通信用増幅器にかか る過電圧は, 機器の電気的な特性の差異よりも, 電源側の 回路構成が大きな影響を与えるため，これを中心に扱うこ ととする。まず, 雷サージがどんな経路で通信装置へ侵入

\footnotetext{
横浜国立大学

厂240-8501 横浜市保土ケ谷区常盤台 79-5

Hirose Labs., Yokohama National University

79-5, Tokiwadai,Hodogaya-ku, Yokohama 240-8501
}

するのか, どのようなサージ源が通信系で問題となるのか, またその性質と伝送特性について検討した。さらに，サー ジとそれに含まれる主要な周波数成分も考慮しつつ, 過電 圧に大きな影響を与えると考えられる接地インピーダン ス, 通信用電源変圧器, 信号伝送と電力伝送を兼祆る通信

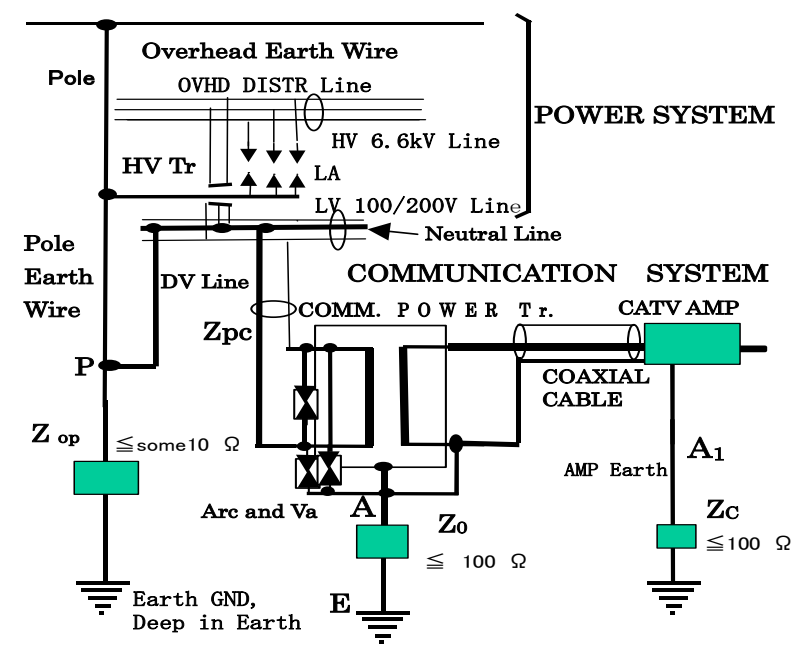

HV Tr : High Voltage TransformerCOMM PWR Tr : Communication Power Transformer Zop : Power Line Earth Impedance ( $\leqq$ some $10 \Omega$ ) Zc : Amplifier Earth Impedance Zpc:Impedance between Zop and Zo,Arc and Va:Communication Arrester and Varister

図 1 配電線から通信装置へのサージ侵入経路の概念図 Fig. 1. Schematic diagram of surge invasion pathway into communication equipment from distribution lines 
機器の入力インピーダンス $75 \Omega の$ 同軸線路などの主要構成 要素について検討した。次いで, 通信システム全体の等価 回路を考え, 過渡解析により過電圧を定量的に評価し, そ の性質を明らかにした。また，この結果をもとに，フィー ルドテスト結果の検討, 通信装置の保護対策についても述 べた。

\section{2. 配電系から通信装置への電力供給とサージ侵 入径路}

図 1 に配電系とそれに接続された通信系システムの主要 部分を示す。電力は高圧配電線から避雷器 LA で保護された 高圧変圧器により低圧配電線に給電され, さらに, 通信用 電源変圧器を介して通信信号伝送と兼用の同軸線路により CATV 中継増幅器に給電される。接地系については, 高圧配 電線の架空地線は電柱の接地線を通して, 変圧器の低圧側 配電線の中性線や架空共同地線による避雷器の接地線とも 接続された $\mathrm{P}$ 点で, 接地インピーダンス $\mathrm{Z}_{\mathrm{op}}$ を介して接地さ れている。低圧配電線に DV 線（引込用ビニル絶縁電線）で 接続された通信用電源変圧器は接地インピーダンス $\mathrm{Z}_{\mathrm{o}}$ を介 して, また同軸線路の外部導体と接続されている増幅器の 接地筐体はインピーダンス $\mathrm{Z}_{\mathrm{c}}$ を介して接地されている。

雷等によって生じたサージの配電系から通信系への伝搬 径路は次のように考えられる。

サージが架空地線や避雷器 LA からサージ電流として配 電柱の接地線を通り, その接地インピーダンス $\mathrm{Z}_{\mathrm{op}}$ に流れて 大地 $\mathrm{E}$ に至ると，接地点 $\mathrm{P}$ の電位が上昇する。これに伴い この点に接続されている低圧配電線と通信用電源変圧器の 一次側の電位が上昇する。これにより 400〜 $500 \mathrm{~V}$ 程度でも 作動する過電圧保護用の通信用避雷器 Arc やバリスターVa が極く短時間で通電，短絡し，低圧配電線の中性線が通信 用電源装置の接地インピーダンス $\mathrm{Z}_{\mathrm{o}}$ に $\mathrm{A}$ 点でつながり,さ らに増幅器に至る同軸線路の接地された外部導体系ともつ ながった状態になる。この結果, サージによる A 点の電位 上昇が同軸線路を通して伝わり, CATV 増幅器等の通信設備 に過電圧がかかり様々な障害が起きる。以下このような事 象を雷サージ電流によって生ずる過電圧と呼ぶ。

\section{3. 配電系に流れるサージ電流とサージ電圧につ いて}

配電系から通信系に流れる雷サージには上記のサージ電 流と以下に述べるサージ電圧がある。雷撃に起因するサー ジ電流には, 直撃雷により架空地線から接地線に直接流れ るものと, 誘導雷により高圧配電線から変圧器の避雷器を 通り接地線に流れる二つがある。サージ電圧は落雷による 電磁誘導によって配電線に誘起されるもので, 配電用変圧 器などを経て通信系に伝わる。

〈3・1〉 高圧配電系に流れるサージ電流とサージ電圧

直撃雷による架空地線からのサージ電流は日本における 推奨の雷電流波高值累積頻度分布によると $50 \%$ 值が $26 \mathrm{kA}$ にもなる電流であり ${ }^{(2)}$, 通信機器類に決定的な損傷を与える

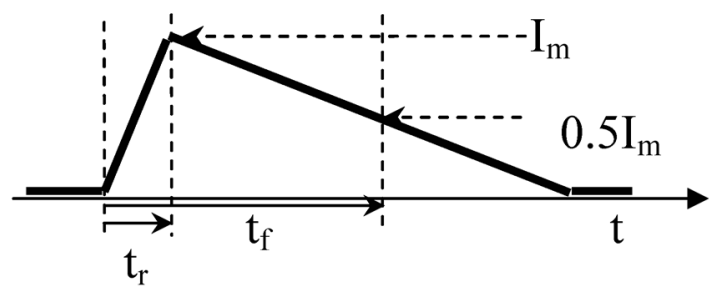

図 2 サージ電流の波形

Fig. 2. Wave form of surge current

が発生頻度は少ない。これに対し, 誘導雷により高圧配電 系の変圧器の避雷器 LA が放電することによるサージ電流 は, 後述のように大きさが一桁程度小さいが発生頻度が高 く通信機器をしばしば損傷する。本論文ではこのサージ電 流によって生ずる過電圧を中心に扱うこととする。

このサージ電流波形としては図 2 のものがよく用いられ る。サージ電流による過電圧の評価には, 立上り時間 $\mathrm{t}_{\mathrm{r}}$ とピ ーク值 $\mathrm{I}_{\mathrm{m}}$ が, エネルギーを考える場合には $\mathrm{I}_{\mathrm{m}}$ と継続時間 $\mathrm{t}_{\mathrm{f}}$ が重要である。以下の検討では, 電気学会の文献(3)「避雷 器とその適用」に示される避雷器の放電電流・続流の波形 に相当する $\mathrm{t}_{\mathrm{r}}$ と $\mathrm{t}_{\mathrm{f}}$ が $1.2 \times 50 \mu \mathrm{s}$ の波形を主として用いる。ま た, 遠方雷などより避雷器を経由せずに, 架空地線から電 柱の接地線を経て, $\mathrm{Z}_{\mathrm{op}}$ に流れるサージ電流の波形で, 国際 電気標準会議 $\mathrm{IEC}^{(4)}$ および電気学会の電気工学ハンドブッ ク(4)に在るやや鈍ったエネルギーの小さな $8 \times 20 \mu \mathrm{s}$, エネル ギーの大きな $10 \times 350 \mu \mathrm{s}$ の 2 つ波形も, 上記の避雷器の電 流の場合の効果と比較するため使用する。

サージ電流 $\mathrm{I}_{\mathrm{op}}$ のピーク值 $\mathrm{I}_{\mathrm{m}}$ については, 日本での以前の 実測調査である電気学会技術報告第 33 号 ${ }^{(5)}$ によれば, 避雷 器が動作したときの放電電流波高值とその避雷器の台数の 割合が知られており, 400A が約 50\%, 950A が約 20\%, 2800A 程度が $5 \%$ とする電流值をとる。この放電電流は, 金属酸化 物の特性をもつ避雷器に課電される電圧が規定值に達した ときこれを通して放電するもので，この電流值は図 2 のよ うに急激かつ大幅に変化するため, 通常衝撃電流とも呼ば れ(3), 一般に電流源と考えられている。

以上から，このサージ電流源 $\mathrm{I}_{\mathrm{op}}$ のピーク值 $\mathrm{I}_{\mathrm{m}}$ としては, 電流值 400A，950A，2800A を以下の検討に用いる。

サージ電圧は，配電線の装柱設備が耐えられる電圧とし て伝播する。6.6kV 配電線につながる機器の雷インパルス耐 電圧は $60 \mathrm{kV}$ であり, 通常この電圧值を配電線側の誘起電圧 と考えることにしている( ${ }^{(6)}$ 。このサージ電圧の波形は図 2 に 示す, 急峻な立上りの $\mathrm{t}_{\mathrm{r}}$ と $\mathrm{t}_{\mathrm{f}}$ が $1.2 \times 50 \mu \mathrm{s}$ の波形が使用され る。

〈3·2〉低圧配電系に流れるサージ電流配電系では 問題ないとされる誘導雷などにより高圧配電系の変圧器の 避雷器が放電することによる電流や続流による上述のサー ジ電流の一部が，低圧配電系を経て通信用電源にも侵入し， 通信装置故障の主因となる。頻繁に発生するため, このサ ージに対して, 汎用通信機器の使用システム中での設置位 置や線路の分岐数を考慮した適切な過電圧保護対策が必要 


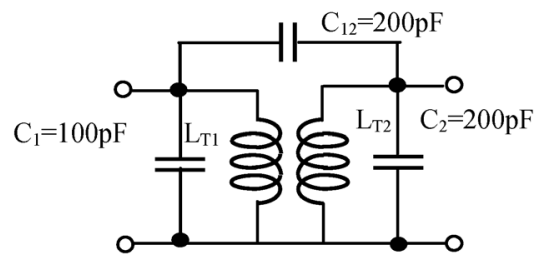

図 3 通信用変圧器の等価回路

Fig. 3. Equiv circuit of comm. transformer

になる。

〈3.3〉配電系に現れるサージ電圧と伝達特性前述 の配電線側で誘起されたサージ電圧が高圧配電線用変圧 器, 低圧配電線を介して給電される通信用変圧器を通して 通信側へどの程度移行するかを, 実験結果 ${ }^{(7)} に$ 基づき検討す る。

（1）高圧配電用変圧器のサージ電圧伝達特性

インパルス電圧を用いた実験により次のことが確かめら れている。高圧配電用変圧器は， 1 次側に $60 \mathrm{kV}$ のサージ電 圧が加わると，2 次側の相間には殆ど移行しないで，相一大 地間に移行するが，その大きさは高々 $1 \mathrm{kV}$ 程度であること が知られている(7)。

(2) 通信用電源変圧器のサージ電圧伝達特性

次に，低圧配電線から通信用電源に加わるサージ電圧を 考える。数百 VA 程度の通信用電源変圧器の 1 次, 2 次間に 遮蔽層がある場合は殆ど移行せず，無い場合は，サージ電 圧の移行は変圧器の浮遊静電容量で殆ど決まる。状況にも よるが, 図 3 に示すように, この静電容量は 1 次側に $\mathrm{C}_{1}$ と して $100 \mathrm{pF}$ 程度, 1 次側と 2 次側間に $\mathrm{C}_{12}$ として $200 \mathrm{pF}$ 程度, 2 次側に $\mathrm{C}_{2}$ として $200 \mathrm{pF}$ 程度である。この場合, サージ電 圧の $1 / 2$ 程度が 1 次側から 2 次側一伝わるが, 通信装置の最 も大きくなる過電圧の検討では, サージ電圧の影響はサー ジ電流の影響に較べて普通充分小さくなり，大まかな検討 を主眼にして，以降はサージ電圧の影響を省くこととした。

\section{4. 通信用電源装置に流れるサージ電流と接地イ ンピーダンス}

配電系から通信系に至るサージ電流の径路と大きさは次 の通りである。

〈4·1〉 サージ電流が流れる経路と回路素子 図4 に2 章で述べたサージ電流が流れる主要な径路を示した。避雷 器の放電や続流であるサージ電流 $\mathrm{I}_{\mathrm{op}}$ の大部分は主に配電系 接地インピーダンス $\mathrm{Z}_{\mathrm{op}}$ を通り大地深層 $\mathrm{E}$ に流れる。 $\mathrm{Z}_{\mathrm{op}}$ が $10 \Omega$ 前後のとき, サージ電流のピーク值が $400 \mathrm{~A}$ 程度のもの が流れると接地点 $\mathrm{P}$ の電位上昇は $4000 \mathrm{~V}$ 程度にもなる。こ の $\mathrm{P}$ 点は低圧配電線の中性線と接続されており，この中性 線, 引込み線などのインピーダンス $\mathrm{Z}_{\mathrm{pc}}$ を通して通信用電源 装置の接地インピーダンス $\mathrm{Z}_{\mathrm{o}}$ と $\mathrm{A}$ 点で繋がる。従って, サ ージ電流 $\mathrm{I}_{\mathrm{op}}$ の一部 $\mathrm{I}_{\mathrm{o}}$ は $\mathrm{Z}_{\mathrm{pc}}$ を通って, さらに主に通信系接 地インピーダンス $Z_{\mathrm{o}}$ を通って大地深層 $\mathrm{E}$ に流れる。

〈4・2〉接地インピーダンス 敷設環境が通信系と殆

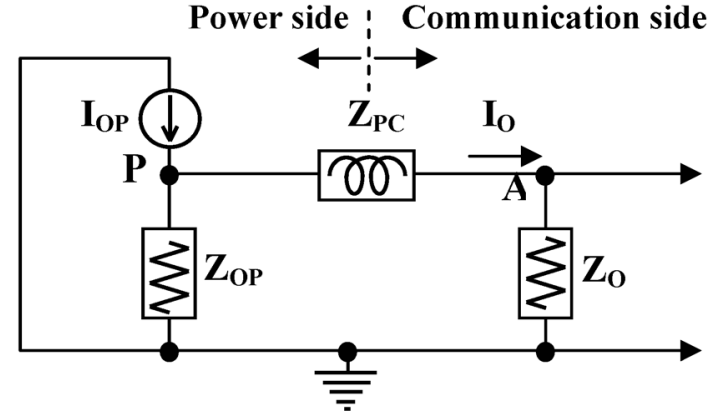

図 4 サージ電流 $\mathrm{I}_{\mathrm{op}}$ と通信系サージ電流 $\mathrm{I}_{0}$

Fig. 4. Relation between surge current $\mathrm{I}_{\mathrm{op}}$ and $\mathrm{I}_{0}$

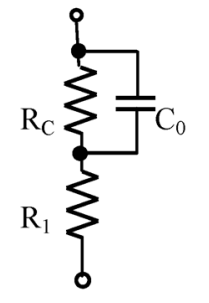

(a)Capasitive type

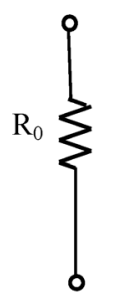

(b)Resistive type ypical kind of earth impedance

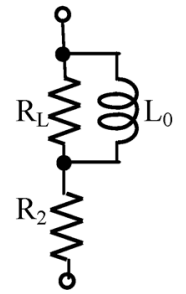

(c)Inductive type
図 5 通信用電源装置の接地インピーダンス

Fig. 5. Earth impedance of comm. source equipment

ど同じである配電系の接地インピーダンスを通信用電源装 置に適用する。サージへの使用周波数限界はあろうが, 図 5 に示寸容量性, 平たん性, 誘導性の 3 種類が知られている。

(a) 容量性回路: 静電容量 $\mathrm{C}_{\mathrm{o}}$ と抵抗 $\mathrm{R}_{\mathrm{c}}$ との並列回路に直 列回路 $\mathrm{R}_{1}$ が接続された等価回路であり, 配電系で多い。代 表例は， $\mathrm{C}_{\mathrm{o}}=0.025 \times 10^{-6} \mathrm{~F}, \mathrm{R}_{\mathrm{c}}=40 \Omega, \mathrm{R}_{1}=30 \Omega^{(8)}$ である。

(b) 平たん性回路: 抵抗 $\mathrm{R}_{\mathrm{o}}$ で表される場合で, 代表例は, $\mathrm{R}_{\mathrm{o}}=10 \Omega, 30 \Omega, 100 \Omega$ などがある。

(c) 誘導性回路：インダクタンス $\mathrm{L}_{\mathrm{o}}$ と抵抗 $\mathrm{R}_{\mathrm{L}}$ との並列 回路に直列抵抗 $\mathrm{R}_{2}$ が接続された等価回路で, 変電所などの 設備で多いとされている。代表例は, $\mathrm{L}_{\mathrm{o}}=40 \times 10^{-6} \mathrm{H}, \mathrm{R}_{\mathrm{L}}=40$ $\Omega, \mathrm{R}_{2}=8 \Omega^{(8)}$ である。

(1) 配電系接地インピーダンス

配電用避雷器の接地は, 避雷器単独の場合は $10 \Omega$ 以下と 定められているが，接地抵抗值を低くすることはそれ程容 易なことではなく, 配電用変圧器などと近接して敷設する 場合には共同接地することが許されている。この場合, 配 電系の接地インピーダンス $\mathrm{Z}_{\mathrm{op}}$ は, 避雷器, 変圧器などの接 地抵抗の影響を加味したものとなる。

ところで，過渡解析に必要な上記の $10 \Omega$ 程度の低い接地 インピーダンスの例が殁どみられない。また，さらに低い 值の局舎や鉄塔塔脚の例が報告されている程度で, 地中状 況も分かっていないことが多い。そのため, 配電系の接地 インピーダンス $Z_{\mathrm{op}}$ は従来知られている接地抵抗を用いて 解析を行う。配電で用いられる避雷器の接地抵抗, 変圧器 と架空共同地線の接地抵抗の組み合わせには $(30 \Omega, 85 \Omega)$, 
$(75 \Omega, 20 \Omega)$ などが多く，これらを合成した $Z_{\mathrm{op}}$ は各々 22 $\Omega, 16 \Omega$ 程度となるので, 以下では図 1 に示す $Z_{\text {op }}$ を $16 \Omega$ と する。

(2) 通信用機器の接地インピーダンス

通信用電源装置に施される接地は，電柱に設置した場合 の機器用であり, 基礎のしっかりした局舎の場合の接地と 異なって，殆どの場合電気設備技術基準の D 種に定められ た接地である。その抵抗值は環境条件や季節的な変化もあ り，不明な点が多いが $100 \Omega$ 程度と考えられる。以下の検討 では接地インピーダンス $Z_{0}$ として, 配電系と殆ど同じ環境 でのものとして報告されている（財）電力中央研究所の報 告にある容量性 ${ }^{(2)} の 70 \Omega^{\left({ }^{(8)}\right.}$ 程度のものを採用し, 必要に応じ て抵抗素子值を変化させて用いる。

通信用中継増幅器の接地インピーダンス $\mathrm{Z}_{\mathrm{c}}$ は, 影響が局 部的であることから $100 \Omega の$ 抵抗を用いる。なお, 中継器用 の接地リード線のインダクタンスが直列に加わる。

\section{〈4·3〉配電系から通信系への経路のインピーダンス}

$Z_{p c}$ 低圧配電線の中性線と低圧配電線から分岐して通信 装置に引き込む $\mathrm{DV}$ 線を合わせた経路のインピーダンス $\mathrm{Z}_{\mathrm{pc}}$ を求める。低圧配電線は地上 $9 \mathrm{~m}$ 程度あるが, 引込み線では 地上高は低くなり $6 \mathrm{~m}$ 程度である。

線路の抵抗成分は $1 \Omega$ 程度と小さく, 線路の対地間のキャ パシタンスは, サージに含まれる主要周波数成分に対して インピーダンスが $1 \mathrm{k} \Omega$ 以上と大きくなるため, 何れも無視 でき, 線路のインダクタンスのみを考慮すれば良いと考え る。

本論文では，サージに含まれる周波数成分のうち，特に 機器の絶縁破壊に影響の大きい $500 \mathrm{kHz}$ 以下の周波数成 分 ${ }^{(9)}$, 必要に応じ $200-300 \mathrm{kHz}$ 程度を念頭において過電圧を 評価する。ただし，インダクタンスの評価では表皮効果は 大きめの周波数 $1 \mathrm{MHz}$ でも殆ど効かないので考慮せずに, 直線状の単線の場合, 大地が零電位面の場合, 大地帰路を 第三紀以降の平地で相当大地面の深さが $300 \mathrm{~m}$ 程度とする 場合の, 3 通りについて付録 1 の算出式を用いて求めた。得 られた $\mathrm{Z}_{\mathrm{pc}}$ のインダクタンス $\mathrm{L}$ は, DV 線では上記の 3 通り の場合について, 過電圧の影響が大きく, よく用いられる 引込み線の長さ $30 \mathrm{~m}$ を想定すると各々 $59 \mu \mathrm{H}, 81 \mu \mathrm{H}, 109 \mu$ $\mathrm{H}$ 程度, ACSR-OW (屋外用鋼心アルミ導体ビニル絶縁電線) と DV 線の組合せでは, 各々 $76 \mu \mathrm{H}, 99 \mu \mathrm{H}, 118 \mu \mathrm{H}$ 程度が得 られた。このように引込み線に異なる導体の組合せを含め 複数について L の值を評価したが，L の值はほぼ 60〜120 $\mu \mathrm{H}$ の範囲にある。以下は最も簡単な DV 線のみの場合と し, 3 通りの算出值の平均值とし, やや短めの $20 \mathrm{~m}$ 程度で も L の值に大差のない $63.7 \mu \mathrm{H}$ を用いた。

\section{5. 通信系システムの等価回路について}

〈5·1〉通信システムとサージ電流の流れサージの 影響を受ける通信システムは図 4 の回路に中継増幅器一至 る同軸線路系を含めて構成されている。通信機器の配置も 含め図 6 に示す。

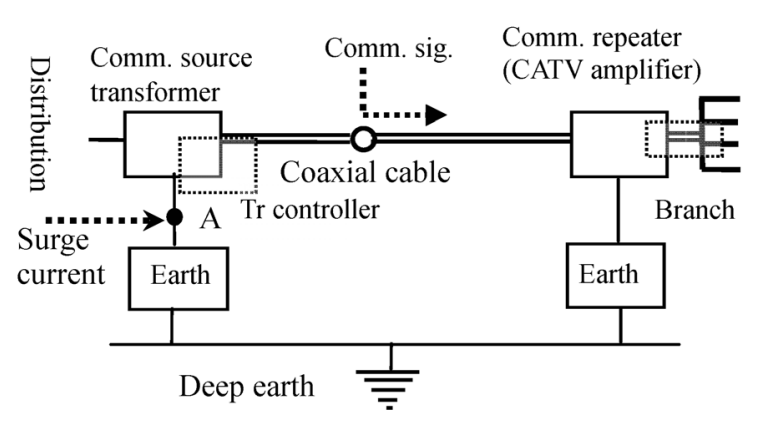

図 6 通信装置の構成と信号の流れ

Fig. 6. Diagram and signal flow of comm. equipment

(1) サージ電流の流れ

サージ電流が通信用電源装置の接地点 $\mathrm{A}$ に侵入し，その 電位を上昇させるとともに, 通信用電源装置, 同軸線路お よび通信用中継装置など同時に多方向を経て, 最終的に大 地深層に電流が流れる。この場合, 同軸線路でのサージ電 流の伝搬は本来の信号電流のそれとは異なる。

（2）サージ電流の同軸線路中の進行

通常の高周波信号が同軸線路を通して伝送される場合, 信号電圧は中心導体と外部導体間に加え, 中心導体に信号 電流が流れれば，外部導体には同じ電流が逆方向に流れる。

これと異なり，サージ電流が同軸線路中を伝わる場合， 入射端から出射端に向かって, 中心導体および外部導体の 両方を通って同じ方向に流れ, CATV 増幅器の接地インピー ダンスを通して大地に, さらに大地を通って, 等価的には 大地内の鏡像導体を通って還流寸る ${ }^{(10)}$ 。すなわち, 同軸線 路を流れるサージ電流は, 地上部の同軸線路の中心導体, 外部導体，および地表を零電位とする地中部の鏡像同軸中 心導体と外部導体で地上と反対方向に流れるので, 4 つの多 導体系の線路としての取扱いを必要とする。

〈5·2〉 サージに対する同軸線路の回路定数同軸線 路のインダクタンスの評価には前述の多導体系線路モデル を用いる。自己インダクタンス成分の評価では, 同軸外部 導体は非磁性であるため磁束の遮蔽効果が無いこと, 相互 誘導については地上と地中鏡像による 4 導体系を考慮する 必要がある。

同軸線路の自己，相互インダクタンスの評価には幾何学

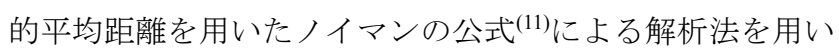
る. 通常の多導体系との差異は, 同軸構造内の限られた空 間での磁界の有無と相互作用の有無とを組合せて考慮する もので, 内部導体の半径を $2.175 \times 10^{-3} \mathrm{~m}$, 外部導体の内半径 を $8.8 \times 10^{-3} \mathrm{~m}$, 導体の地上高を $6 \mathrm{~m}$, 真空の透磁率 $\mu_{0}$ を $4 \pi$ $\times 10^{-7} \mathrm{H} / \mathrm{m}$ とすると, 線路長 $400 \mathrm{~m}$ では $\mathrm{L}_{1}, \mathrm{~L}_{2}$ はそれぞれ $0.69 \mathrm{mH}, 0.57 \mathrm{mH}, \mathrm{M}_{12}$ は $0.57 \mathrm{mH}$ となる。

キャパシタンス成分については，同軸外部導体は金属に よる遮蔽効果があるため，地上の 2 導体のみを考慮する。

次節で述べる同軸線路の $\pi$ 型等価回路を考える場合, 中 心導体一外部導体間, 外部導体一大地間のキャパシタンス 成分の值は, 同軸円筒状の線電荷と影像法により評価し, 
同軸線路の入射端や出射端に分割して配置する。

\section{$\langle 5 \cdot 3\rangle$ 通信系の等価回路}

(1) 同軸線路

サージが架空線路や同軸線路を伝搬する場合の速度は $200 \times 10^{6} \sim 300 \times 10^{6} \mathrm{~m} / \mathrm{s}$ 程度となる。サージに含まれる $500 \mathrm{kHz}$ 以下の周波数成分では, 波長は 400 600m 程度以上となる。 増幅器間の同軸線路の長さはよく用いられる $400 \mathrm{~m}$ とし, 同 軸線路の等価回路には, 入射端や出射端での回路接続を考 慮して, 図 7 のような $\pi$ 型 1 段の集中定数回路を用いる。

中心導体と外部導体間のキャパシタンスは長さ $400 \mathrm{~m} の$ 場合， $27 \mathrm{nF}$ であり，外部導体と大地間では $3.2 \mathrm{nF}$ である。 サージの周波数成分に対しては，各々数 $10 \Omega$ 以上，数 100 $\Omega$ 以上である。

\section{(2) 中継増幅器関係の部分}

同軸線路の出射端に接続される増幅器自体の入力インピ ーダンスは，容量性結合した場合，周波数に逆比例するの で，サージの周波数では信号周波数とサージの周波数の比 だけ信号の入力インピーダンスが高くなるので省略する。 中継増幅器以降の同軸線路の分岐数がサージに対しては影 響するので，分岐数と特性インピーダンスを考慮したイン ピーダンスを出射端に接続する。増幅器の接地インピーダ

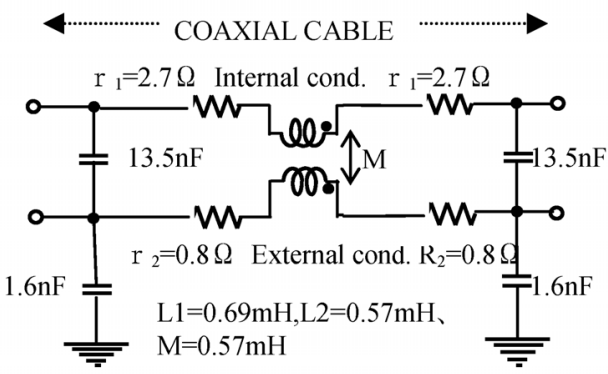

図 7 同軸線路の等価回路

Fig. 7. Equiv. circuit of coaxial cable for surge curr.
ンスは，接地線のインダクタンスと接地抵抗が主となり， サージの主要周波数成分に対して数 $100 \Omega$ 程度となる。

〈5・4〉 通信システムのモデル化と等価回路＼cjkstart前節ま での考察をもとに, 配電系からのサージ電流源, 通信用電 源装置，増幅器とそれに給電寸る同軸線路からなる通信シ ステムのサージに対する等価回路を図 8 に示す。後述の過 渡解析に用いる素子定数の例を図中に示す。以下，重要部 分について説明する。

(1) 配電系から通信用電源変圧器までの部分

電力配電系の部分は, 通信用変圧器入力側の過電圧保護 用の通信用避雷器やバリスターが通電した状態で, 図 4 の サージ電流の流れる径路で示した通りである。P 点が配電系 の接地インピーダンス $Z_{\mathrm{op}}$, $\mathrm{A}$ 点が変圧器の接地インピーダ ンス $Z_{\mathrm{o}}$ で接地されている。一例として, $\mathrm{Z}_{\mathrm{op}}=16 \Omega, \mathrm{Z}_{\mathrm{PC}}$ のイ ンダクタンス $63.7 \mu \mathrm{H}$, 同抵抗 $0.48 \Omega, Z_{\mathrm{o}}$ としては図 5(a)の ものを $\mathrm{R}_{\mathrm{C}}=40 \Omega, \mathrm{C}_{\mathrm{o}}=0.025 \mu \mathrm{F}, \mathrm{R}_{1}=30 \Omega$ として用いた。

(2) 通信用変圧器及び DV 線の部分

通信用変圧器の部分は, 図 3 に示した変圧器の等価回路 であり，インダクタンス值の例は, $\mathrm{L}_{\mathrm{T} 1}=35 \mathrm{mH}, \mathrm{L}_{\mathrm{T} 2}=29 \mathrm{mH}$, 結合係数 $\mathrm{k}=1$, 浮遊静電容量は同図に示した值とした。変圧 器の 1 次側に接続された長さ $20 \mathrm{~m} の \mathrm{DV}$ 線の部分は, 両側 の二つの静電容量で中央のインダクタンスを挟んだ $\pi$ 型等 価回路で模擬し, サージに影響する右半分のキャパシタン ス部分のみ用いる。図 8 の変圧器一次側の各相一大地間の 容量 $\mathrm{C}_{\mathrm{D} 1}$ として $60 \mathrm{pF}, \mathrm{C}_{\mathrm{D} 2}$ として $60 \mathrm{pF}$, 相間の容量 $\mathrm{C}_{\mathrm{D} 3}$ と して $1170 \mathrm{pF}$ とた。変圧器 2 次側のノイズ対策用の容量 $\mathrm{C}_{\mathrm{D} 4}$ としては $2000 \mathrm{pF}$ を用いた。

\section{(3) 同軸線路部分}

同軸線路部分は等価回路を〈5·3〉節( 1 )で説明した通り で，図 7 に示した数值例を用いた。同軸線路としては PSACOX-17C (17C-CATV 用アルミニウムパイプ形同軸ケー ブル)を地上 $6 \mathrm{~m}$ の高さに長さ $400 \mathrm{~m}$ で敷設した場合を考え た。この場合の雷などのサージに対する線路定数は〈5·2

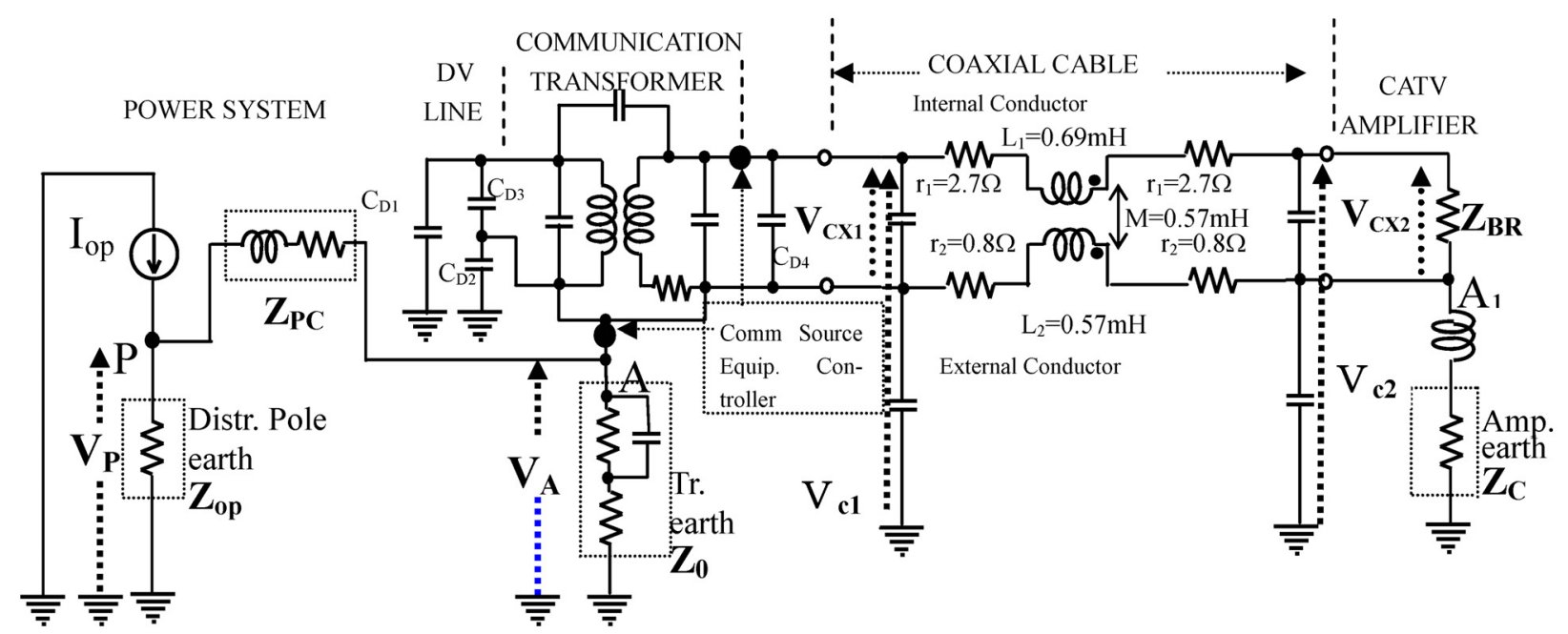

図 8 通信システムのモデル回路

Fig. 8. Model circuit of communication systems 
節で述べた方法で求まり，図７に示したものを用いた。

(4) 中継増幅器およびその接地部分

同軸線路出射端から中継器を見込むインピーダンス $Z_{\mathrm{BR}}$ は, 増幅器入力インピーダンスと次の区間への同軸線路（図 6 の CATV amplifier 出力側の線路）のインピーダンスを並列 合成したものとなる。通常，通信信号に対してはインピー ダンス整合をとるが，サージに対しては別途考慮する必要 がある。又，次段以降の簡略化を考えるものとする。

中継増幅器自体の入力インピーダンスはサージの周波数 では高く無視できる。中継増幅器から次の区間に至る同軸 線路は，需要家に分配するため分岐する。分岐無しから 5 分岐程度まであり，サージに対する同軸線路単線の特性イ ンピーダンスを基に同軸線路の分岐を考慮した值をインピ 一ダンス $Z_{\mathrm{BR}}$ とする。その值は分岐線無しの場合の $10 \mathrm{k} \Omega$, $530 \Omega$ ，単線を延長した場合の $265 \Omega ， 132 \Omega ， 66 \Omega ， 5$ 分岐 線相当の場合の $53 \Omega$ とした。

CATV 中継増幅器の接地は, 図 8 の $\mathrm{A}_{1}$ 点で接地インピー ダンス $Z_{\mathrm{c}}$ により接地されている。具体的には, 中継器から 接地用リード線により, 吊架線, 電柱に沿って電柱近傍の 大地に接地する。中継器の接地は, 接地リード線が $20 \mathrm{~m}$ 長 程度の場合，そのインダクタンスが $39 \mu \mathrm{H}$ となり，接地抵 抗值 $100 \Omega$ に直列に加わる。

\section{6. 過渡解析}

〈6.1〉過渡解析のパラメター 図 8 のモデル回路に サージ電流源 $\mathrm{I}_{\mathrm{op}}$ を印加して次の過電圧值を PSpice シュミレ ータによる過渡解析で評価した。サージ電流源 $\mathrm{I}_{\mathrm{op}}$ の振幅 $\mathrm{I}_{\mathrm{m}}$ は $\langle 3 \cdot 1\rangle$ 節(2)で述べた 400A，950A，2,800A とした。サ ージ電流波形の $\mathrm{t}_{\mathrm{r}}, \mathrm{t}_{\mathrm{f}}$ としては $\langle 3 \cdot 1\rangle$ 節( 1 )で述べた 3 種類 を用いた。

(1) 通信系システムが最も大きい影響を受ける接地点 $\mathrm{A}$ の電位 $\mathrm{V}_{\mathrm{A}}$ を検討する。この上昇值が通信システム各機器の 受ける過電圧の基本となる。

(2) サージが侵入する接地点 $\mathrm{A}$ に最も近い通信用電源装 置の制御装置が受ける過電圧，即ち同軸線路の入射端の電 圧 $\mathrm{V}_{\mathrm{CX} 1}$ と対地電位 $\mathrm{V}_{\mathrm{c} 1}$ の上昇を検討する。

(3) 中継増幅器が受ける過電圧，すなわち同軸線路の出 射端の電圧 $V_{\mathrm{CX} 2}$ と対地電位 $\mathrm{V}_{\mathrm{c} 2}$ の上昇を検討する。

\section{$\langle 6 \cdot 2\rangle \quad$ 過渡解析結果}

\section{i ）通信システムの接地点に現れる電位上昇と機器の過} 電圧

サージ電流 $\mathrm{I}_{\mathrm{op}}$ の振幅 $\mathrm{I}_{\mathrm{m}}$ を $1 \mathrm{~A}$ として, $1.2 \times 50 \mu \mathrm{s}$ の波形を 印加した時の前述の接地点電位 $\mathrm{V}_{\mathrm{p}}$ と $\mathrm{V}_{\mathrm{A}}$, 同軸入射端電位 $\mathrm{V}_{\mathrm{c} 1}$, 同軸出射端電圧 $\mathrm{V}_{\mathrm{CX} 2}$ と対地電位 $\mathrm{V}_{\mathrm{c} 2}$ の解析例を電流源 $\mathrm{I}_{\mathrm{op}}$ の波形とともに図 9 に示した。図 8 の回路は線形であり, 前述のサージ電流の振幅の 400A, 950A, 2800A に対する過電 圧を求めるには結果に電流值を乗ずれはよい。

$\mathrm{V}_{\mathrm{p}}$ はサージ電流とほぼ同じ波形で大きな振幅， $\mathrm{V}_{\mathrm{A}}$ はピー クが少し鈍り少し遅れるが $\mathrm{V}_{\mathrm{p}}$ に近い波形, $\mathrm{V}_{\mathrm{c} 1}$ は $\mathrm{V}_{\mathrm{A}}$ よりピ ークがやや小さいが，三つの過電圧はサージ電流 $\mathrm{I}_{\mathrm{op}}$ とほぼ

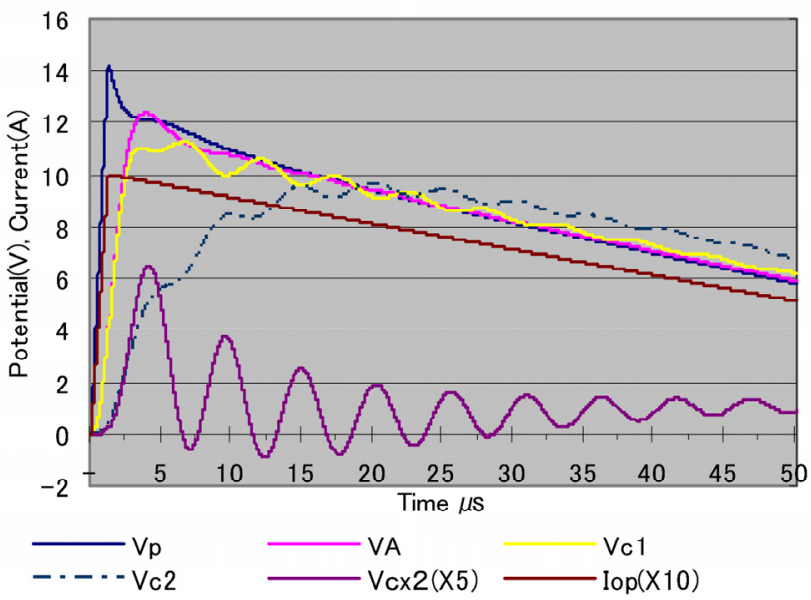

図 9 過電圧波形の解析例

Fig. 9. Example of potentials and overvoltages calculated

表 1 サージ電流による通信用電源接地点電位上昇

Table 1. Potential rise of comm. earth point for different surge current

\begin{tabular}{|c|c|c|c|}
\hline Surge wave & $\mathrm{V}_{\mathrm{A}}(\operatorname{Im} 400 \mathrm{~A})$ & $\mathrm{V}_{\mathrm{A}}(\operatorname{Im} 950 \mathrm{~A})$ & $\mathrm{V}_{\mathrm{A}}(\operatorname{Im} 2800 \mathrm{~A})$ \\
\hline $1.2 \times 50 \mu \mathrm{s}$ & $4,950 \mathrm{~V}$ & $11,760 \mathrm{~V}$ & $34,665 \mathrm{~V}$ \\
\hline $8 \times 20 \mu \mathrm{S}$ & $4,655 \mathrm{~V}$ & $11,060 \mathrm{~V}$ & $32,590 \mathrm{~V}$ \\
\hline $10 \times 350 \mu \mathrm{s}$ & $4,750 \mathrm{~V}$ & $11,275 \mathrm{~V}$ & $33,235 \mathrm{~V}$ \\
\hline
\end{tabular}

Earth impedance of comm. equip. $Z_{0}=70 \Omega$

同じ波形であることが分る。

$\mathrm{V}_{\mathrm{c} 2}$ は $\mathrm{V}_{\mathrm{c} 1}$ よりかなり鈍って出射端に現れる。同軸のイン ダクタンス成分によるものと考えられる。

中継増幅器に加わる過電圧 $\mathrm{V}_{\mathrm{cx} 2}$ は，他の波形と異なり振 動的な波形となる。サージ電流の振幅が前述の数 $100 \mathrm{~A}$ 以上 となるとその振幅は数 $\mathrm{kV}$ 程度にもなる。

次に, サージ電流 $\mathrm{I}_{\mathrm{op}}$ の波形と振幅を変化させたときの通 信用電源の接地点電位 $V_{\mathrm{A}}$ の最大值を表 1 に示す。

接地点電位 $\mathrm{V}_{\mathrm{A}}$ の上昇はサージ電流の振幅によるが 5〜 $35 \mathrm{kV}$ になる。これとほぼ同じ值が通信システム系の通信用 電源制御装置や中継増幅器などの電位上昇として現れる。 通信用電源制御装置や中継増幅器の過電圧 $\mathrm{V}_{\mathrm{cx} 1}, \mathrm{~V}_{\mathrm{cx} 2}$ は $\mathrm{V}_{\mathrm{A}}$ の $10 \sim 12 \%$ 程度となるが，その值は数 $\mathrm{kV}$ にもなる。

サージ電流波形の立上り時間の影響に関しては, 波形の 立上りを $1.2 \mu \mathrm{s}$ から 8〜10 $\mu \mathrm{s}$ とるやかにすると, 接地点電 位 $\mathrm{V}_{\mathrm{A}}$ のピーク值は 6〜 10\%程度低下寸る。

通信系の接地点電位 $\mathrm{V}_{\mathrm{A}}$ のピーク值は配電系接地点電位 $\mathrm{V}_{\mathrm{P}}$ のそれよりもサージ電流波形の立上り時間 $\mathrm{t}_{\mathrm{r}}$ が $1.2 \mu \mathrm{s}$ の場 合で $13 \%, 8 \mu \mathrm{s}$ の場合で $8 \%, 10 \mu \mathrm{s}$ の場合で $5 \%$ 程度低くな る。

ii ）通信システムの主要部分に現れる過電圧と影響を与 える回路のパラメター

(1) 通信用電源の接地点電位 $\mathrm{V}_{\mathrm{A}}$ に与える接地インピーダ ンス $Z_{0}$ の影響

サージ電流による $\mathrm{V}_{\mathrm{A}}$ の電位上昇への接地インピーダンス 


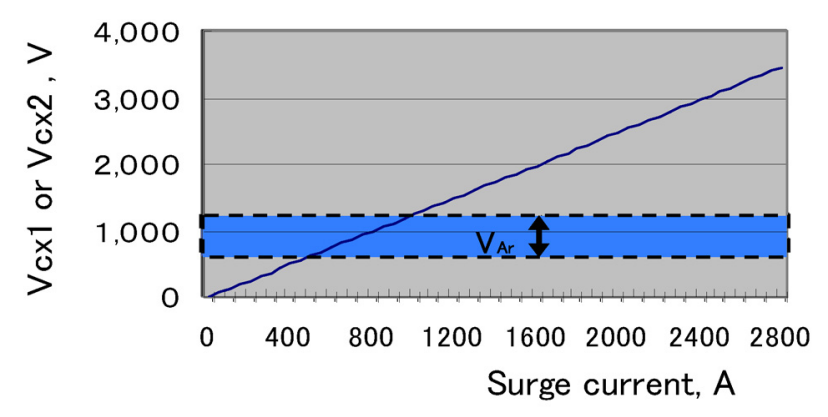

図 10 機器にかかる過電圧と避雷器の制限電圧

Fig. 10. Overvoltage of equip. and breakdown vtg. of arrester

$\mathrm{Z}_{\mathrm{o}}$ の変化による影響は次の通りである。〈4・2〉節で述べた 接地インピーダンスは, その時定数が $1 \mu \mathrm{s}$ 程度であり, サ ージ電流の立上り時間 $\mathrm{t}_{\mathrm{r}}$ 程度を経過すれば，ほぼ抵抗とな

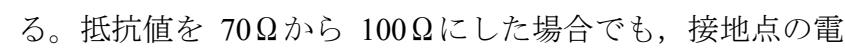
位上昇 $\mathrm{V}_{\mathrm{A}}$ は $5 \%$ 程度の小幅の上昇に止まった。図 4 から分 かるように, 時間の経過に伴い, 配電系接地インピーダン ス $Z_{\mathrm{op}}$ の低い抵抗と通信用電源の接地抵抗 $Z_{\mathrm{o}}$ とが並列状態 となり，抵抗值が頭打ちになるためである。

(2) 通信用電源制御装置, 中継増幅器に加わる過電圧と 保護特性

通信用電源制御装置に加わる過電圧 $\mathrm{V}_{\mathrm{cx} 1}$ は前述の $\mathrm{V}_{\mathrm{A}}$ の上 昇により $500 \mathrm{~V} \sim 4 \mathrm{kV}$ にもなる。通信システム系では最も高 い過電圧が加わる。図 9 の同軸出射端電圧 $\mathrm{V}_{\mathrm{cx} 2}$ が振動的で あることからも分かるように，同軸入射端と出射端の電圧 の極性は異なる場合が多く見られる。この振動的な応答は 同軸線路のインダクタンスと各部のキャパシタンスによる ものと見られるが，保護用に用いられる有極性のコンデン サーやダイオード素子等に悪影響を与える可能性がある。

次に, 制御装置や中継増幅器に加わる過電圧と課電時間 について述べる。増幅器内には過電圧保護装置が数種類あ るが, 代表例がガス避雷器である。その印加電圧と放電動 作開始時間の動作曲線を共に対数軸で表すと, 印加電圧が 少しでも下がると放電動作開始時間が大きく伸びる。従っ て増幅器に加わる過電圧が保護装置の制限電圧の近くに在 れば過電圧の課電時間が長くなり保護特性が低下寸ること が考えられる。

図 10 はサージ電流の振幅 $\mathrm{I}_{\mathrm{m}}$ が変化したとき, 通信用電源 制御装置や中継増幅器などにかかる過電圧 $\mathrm{V}_{\mathrm{cx} 1}, \mathrm{~V}_{\mathrm{cx} 2}$ をガス 避雷器の過電圧制限電圧の範囲 $\mathrm{V}_{\mathrm{Ar}}$ とともに示したもので ある。過電圧が網掛けで示した数 $100 \mathrm{~V} \sim 1000 \mathrm{~V}$ 近くの $\mathrm{V}_{\mathrm{Ar}}$ の範囲内に入ると保護特性が低下寸る。尚, $\mathrm{V}_{\mathrm{Ar}}$ の上限より 高い過電圧の部分も同軸線路インピーダンスの分岐数に依 存する $\mathrm{Z}_{\mathrm{BR}}$ や線路定数, 機器の接地などの回路パラメターに よっては低下してこの範囲に入り，障害を与えることもあ り得る。

なお, 避雷器の制限電圧を超える大きな過電圧が加わる 場合, 避雷器は正常に動作するが, その電流耐量を超える

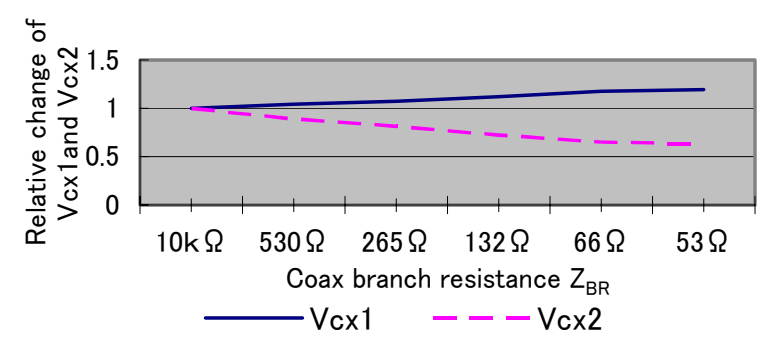

図 11 同軸入出射端電圧 $V_{c x 1}, V_{c x 2}$ と負荷抵抗 $Z_{B R}$ の変化

Fig. 11. Effect of Impedance $Z_{B R}$ to $V_{c x 1}$ and $V_{c x 2}$

と場合によっては破壊する。

このように, 機器にかかる過電圧の大きさと放電開始時 間の両方を考慮した機器の保護特性に要求される指針が, 本論文の過電圧評価の手法により求まり, 保護特性の改善 に役立つと考える。

(3) 通信用電源制御装置, 中継増幅器に加わる過電圧の 変動とその要因

〈5・4〉節( 4 )で述べたように，サージに対する同軸線路 単線の特性インピーダンスを基に同軸線路の分岐を考慮し たインピーダンス $Z_{\mathrm{BR}}$ が図 8 の同軸出射端につながる。この $Z_{\mathrm{BR}}$ を同軸を接続しない $10 \mathrm{k} \Omega$ から順次低くして, 同軸を 5 分岐する場合の $53 \Omega$ に変化させた場合の同軸の入, 出射端 の電圧 $\mathrm{V}_{\mathrm{cx} 1}, \mathrm{~V}_{\mathrm{cx} 2}$ の変化をサージ電流波形 $1.2 \times 50 \mu \mathrm{s}$ の場合 について図 11 に示寸。入射端電圧 $\mathrm{V}_{\mathrm{cx} 1}$ は $20 \%$ 程度増加し, 出射端電圧 $\mathrm{V}_{\mathrm{cx} 2}$ は $40 \%$ 程度減少する。サージ電流波形が $8 \times 20 \mu \mathrm{s}, 10 \times 350 \mu \mathrm{s}$ の場合では, $\mathrm{V}_{\mathrm{cx} 1}$ は 100\%程度増加し, $\mathrm{V}_{\mathrm{cx} 2}$ は $70 \%$ 程度減少する。この $\mathrm{Z}_{\mathrm{BR}}$ の変化は同軸入射端よ り電源側の対地電位には殆ど影響無いことが分かってお り, サージが通信用電源の接地点 A から同軸外部導体側に 流れることと, 外部, 内部導体の自己および相互インダク タンスがあるため電圧, 電流が相互に影響し, 上述の出射 端の電圧の変化および同軸線路の入出射端の電位差をもた らすと考えられる。この電位差は内部導体の方が外部導体 より大きく, 出射端電圧に小さく入射端電圧に大きく影響 している。

以上のように中継増幅器にかかる過電圧 $\mathrm{V}_{\mathrm{cx} 2}$ は同軸分岐 数の違いによって大きく影響され, この節の(2)で述べた過 電圧に対する保護特性に大きな影響を与えるので注意を要 する。

次に, 中継増幅器の接地抵抗 $Z_{\mathrm{c}}$ が変化した場合の過電圧 への影響は， $Z_{\mathrm{c}}$ が $100 \Omega$ から $50 \Omega$ に低くなった場合には, 通信用電源制御装置にかかる電圧 $\mathrm{V}_{\mathrm{cx} 1}$ が $9 \%$ 程度, 中継増幅 器にかかる電圧 $\mathrm{V}_{\mathrm{cx} 2}$ が $10 \%$ 程度高くなる。同軸に繋がる機 器の保護特性の応答が速くなる影響を与える。サージ電流 波形が変わった場合には, $1.2 \times 50 \mu \mathrm{s}$ の場合に比べて, $8 \times 20$ $\mu \mathrm{s}, 10 \times 350 \mu \mathrm{s}$ の場合にはこれらの電圧は 50〜 60\%程度低下 する。

以上述べたように, インピーダンス $Z_{\mathrm{BR}}$, 接地抵抗 $Z_{\mathrm{c}}$, サ ージ電流波形によって機器に加わる過電圧が変動を受ける 
ため，これらを総合した保護特性の把握が必要となる。特 にサージの波形に対しては変化が大きいので，実際に流れ るサージ電流波形の把握は難しいので, 本論文の手法によ って波形による変動範囲を予め評価しておき，対策を施す ことが有効と考えられる。

(4) 通信システムの各機器にかかる過電圧のサージ侵入 点からの配置の影響

図 12 に図 8 の回路に示寸各機器の接地点の電位上昇と同 軸入, 出射端での電圧の一例を示す。サージ電流 $\mathrm{I}_{\mathrm{op}}$ の波形 は $1.2 \times 50 \mu \mathrm{s}$ ，振幅は $\mathrm{I}_{\mathrm{m}}=1 \mathrm{~A}$ とした。配電系の接地点 $\mathrm{P}$ から 右側の中継増幅器に至る途中の電位 $\mathrm{V}_{\mathrm{p}}, \mathrm{V}_{\mathrm{A}}, \mathrm{V}_{\mathrm{c} 1}, \mathrm{~V}_{\mathrm{c} 2}$ は次 第に減少するが, サージ電流の振幅を前述の 400A, 950A, $2800 \mathrm{~A}$ とすると, 同軸出射端 $\mathrm{V}_{\mathrm{c} 2}$ でも数 $\mathrm{kV}$ から数 $10 \mathrm{kV}$ の 高い電位となる。また, 同軸入, 出射端の電圧の大きさに ついては，回路の条件にもよるが，入射端の方が出射端よ りも高い。

(5) 通信用電源変圧器部分の影響について

通信用電源変圧器には浮遊容量があり, 通常過電圧に対 して影響があるが，今回のように電源変圧器の負荷側にサ ージの主要な周波数に対してインピーダンスが低い同軸線 路が接続された場合には，インピーダンスの差異が大きい ため電源変圧器の浮遊容量などの影響が殆ど現れてこない ことが分かった。

\section{iii）同軸線路の長さによる影響}

同軸線路の長さ 1 を $400 \mathrm{~m}$ より長くした場合の影響を図 7 の同軸線路の等価回路定数を計算し直して検討した。その 結果, 表 1 に示寸機器の対地電位 $\mathrm{V}_{\mathrm{A}}$ のピーク值は高くなり, $3 \mathrm{~km}$ 程度で $\mathrm{V}_{\mathrm{p}}$ のそれに等しいかより大きくなる。これは， 長さ 1 の増大と共に線路定数 $\mathrm{L}_{1}, \mathrm{~L}_{2}, \mathrm{C}$ 等が増大するので, 接地点 $\mathrm{A}$ からみた線路側のインピーダンスが大きくなるた めと考えられる。同軸入, 出射端の過電圧值はほぼ同じ程 度であるが，図 9 に示した出射端電圧 $\mathrm{V}_{\mathrm{cx} 2}$ などの振動波形 の周期は，ほぼ同軸線路のインダクタンスとキャパシタン スの積の平方根に比例し, ほぼ線路の長さに比例すること が分った。線路長に依存する線路のインダクタンスとキャ パシタンスが振動の周期を決める重要な要素であることが 判明した。

iv）通信システムに加わる過電圧に影響を及ぼす要素のまとめ

(1) 過電圧に最も大きく影響する要素は，当然ではある

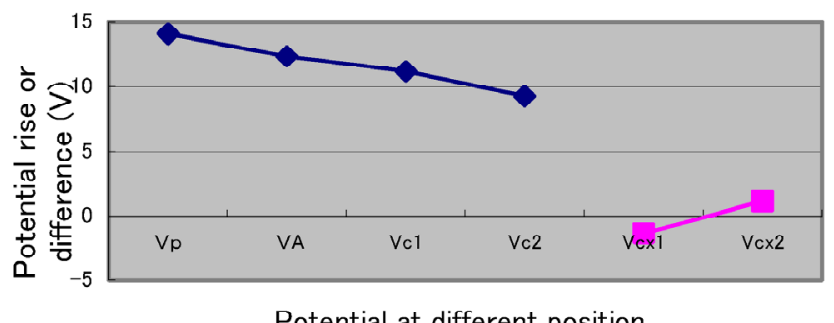

図 12 通信系機器類の対地電位と過電圧例

Fig. 12. Voltage rise of comm. equip by current surge
がサージ電流の大きさ $\mathrm{I}_{\mathrm{m}}$ とその波形, 回路要素では配電系 の接地抵抗 $Z_{\mathrm{op}}$ である。

(2) 次に大きく影響する要素は, 通信用電源の接地イン ピーダンス $Z_{0}$, 中継増幅器内の同軸線路の分岐数に依存す る $Z_{\mathrm{BR}}$, 中継増幅器の接地抵抗 $Z_{\mathrm{c}}$, 同軸の線路長とその線路 定数などである。これらは同軸の入，出射端電圧に大きく 影響する要素でもある。

v ）通信機器の過電圧に対する保護の在り方

中継増幅器の保護特性は, これに加わる過電圧の大きさ や頻度と増幅器内過電圧保護素子の特性の両方に影響さ れ，これにより総合的に定まることになる。

以上, 通信機器に加わる過電圧およびその変動状況を, 通信システムのモデル化を行って検討したが，これらを通 信機器毎により詳細につめることにより, 本論文の手法に より得られた結果の効果がより具体的かつ明らかになると 考える。

\section{7. 雷サージによる通信装置の故障と検討}

はじめにでも述べたが，筆者の一人は関東一円に亘る 10 万軒を超える需要家に供給する CATV 通信システムのフィ ールド調査を通信装置類の雷害故障について行って, 機器 約 1 万台の 2 力年間の故障である百数十件のデータを調べ た。

以下では本論文の手法で得られた各部の過電圧の性質を 念頭におき，雷害による故障について考察する。

調査した通信システムは三つに分けられる。一つは CATV システムの情報源を収集・送出する設備で山頂などに設置 されてシステムセンターと呼ばれている。そこには前置増 幅器 PA やへッドエンド増幅器 HA が備えられている。二つ 目はこのセンターと需要家を結ぶ伝送・分配部分であり, 同軸線路 (Cable; CBL) と信号を増幅 (Amplify; A) ・分配 (Distribute; D) する数種類の中継増幅器が使われる。これら は信号伝送機能で区別しており，同軸幹線 (Trunc; T) の中 継および分配に用いる増幅器で主幹線 (Main; M) 用の M-TA, M-TDA, M-TBA やM-A があり, 同軸の分岐・分配 に用いる増幅器の D-BA や D-EA がある。三つ目は, 通信用 電源装置である電源変圧器と無停電電源およびその制御装 置を含む電源供給機 PS, 伝送設備の最末端で信号を需要家 に分配するフェライトコア，コイルなどの受動素子ででき

Surge fault rate of equipment

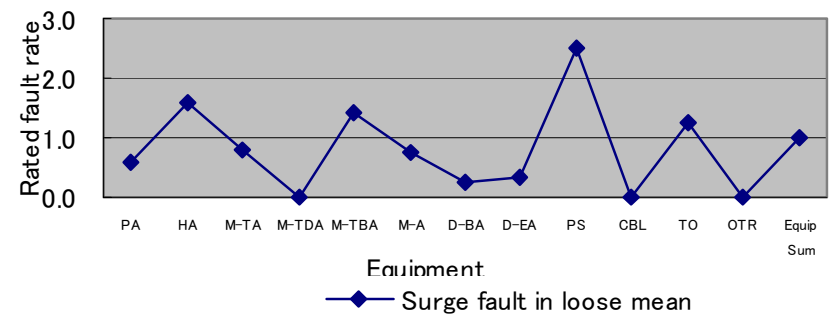

図 13 通信機器の故障比率例

Fig. 13. Fault rate examples of field comm. equip 
ているタップオフ TO などがある。

雷害による各装置の故障部分としては, 電源部, ヒュー ズ, ブレーカ, AVR などがある。各機器毎にこれらの雷害 を集計し, 全体の平均故障率を 1 として, その比率を示し たものが図 13 である。サージ電流が小さく頻度も多い遠方 雷などによる雷害の可能性のある場合も含めた広義 (loose mean) の雷害故障 (surge fault) 比率を示した。これには, 近 傍の落雷などによる障害である狭義の雷障害が 7 割程度含 まれており, 両者の影響の傾向はほぼ同じで, 両方の雷障 害の影響が共通して大きい機器が明確となった。これにつ いて，以下の例で述べる。

故障が特に多い機器は, 総数 2,800 台の通信用電源装置 PS で全体の平均故障率の 2.5 倍, 総数 3,280 台の M-TBA で 1.5 倍, 4 分岐相当で約 51,000 台の TO の広・狭義の故障で 1.2〜2.2 倍などである。以下ではこれらを中心に述べる。

〈7·1〉通信用電源装置 PSについて PS は図 8 の電 源用接地点 $\mathrm{A}$ とこれに繋がる通信用電源変圧器の部分で, 図 12 に示した $V_{A}$ および $V_{c 1}$ の電位上昇と同軸入射端の過電 圧 $\mathrm{V}_{\mathrm{cx} 1}$ が加わる。サージ電流の振幅 $\mathrm{I}_{\mathrm{m}}$ が 400A〜2800A では, 電位上昇が $5 \sim 35 \mathrm{kV}$ ，過電圧が $500 \mathrm{~V} \sim 4 \mathrm{kV}$ となる。

ここで注意して置きたいことは, 同軸入射端の過電圧 $V_{\mathrm{cx} 1}$ は通信用機器の接地状態に強く依存する比較的小さな值の 電圧であるが，対地電位 $\mathrm{V}_{\mathrm{A}}, \mathrm{V}_{\mathrm{c} 1}$ にも大きく影響される。こ れらは $\langle 6 \cdot 2\rangle$ 節 ii の(2)に述べたように配電系の接地インピ 一ダンス $Z_{\mathrm{op}}$ とその変動に左右される。例えばサージ電流の 発生に際し, 多重雷や隣接した落雷など配電系の接地状態 の変化などに強く影響を受ける可能性が考えられる。

フューズやブレーカ等は保護機能と簡便さから当然必要 ではあるが，一層の保護性能の向上を図り，人手による故 障調査と保守方法を少しでも改良するためには，例えば， 過電流などを検知して電源遮断の一定時間後に自動回復す る遮断方式などの開発が必要であろう。

$\langle 7 \cdot 2\rangle$ 幹線の増幅器と分岐線の増幅器について PS に次いで雷害故障比率が大きいのは M-TBA の 1.5 である。 M-TBA は図 8 の同軸幹線の右端 CATV AMPLIFIER の位置 にある。機能が殆ど同じではあるが幹線増幅器で同軸が分 岐した下段に設置された分岐増幅器 D-BA の故障比率 0.25 はこれに比べて $1 / 6$ 程度になる。これは分岐などにより過電 圧が低減されるためと考える。即ち，M-TBA には図 12 に 示した対地電位 $\mathrm{V}_{\mathrm{c} 2}$ と過電圧 $\mathrm{V}_{\mathrm{cx} 2}$ が加わり, D-BA には前段 の M-TBA の内部の同軸の分岐によるインピーダンス $\mathrm{Z}_{\mathrm{BR}}$ に よって図 11 に示されるように低下した過電圧がかかる。例 えば， 5 分岐が 2 段重なると $0.6 \times 0.6=0.36$ ，これが更に 2 段 重なると $1 / 6$ 程度に低減する。低減が 0.16 では, M-TBA の 過電圧 $500 \mathrm{~V} \sim 4 \mathrm{kV}$ が D-BA では 80〜 640V となり，この值 は避雷器の放電動作電圧 $\mathrm{V}_{\mathrm{Ar}}$ 以下か下限に近い值になる。過 電圧の低下が直ちに故障比率の低下になるとは限らない が, 避雷器の放電動作開始時間が伸びて, 保護性能が低下 する恐れがでてくる。なお，過電圧が更に低下して数 $100 \mathrm{~V}$ 程度以下になれば, 避雷器の必要性も少なくなり, 実用上
かなりの故障低減効果がみられると考える。従って, 増幅 器に加わる過電圧 $\mathrm{V}_{\mathrm{cx} 2}$ が避雷器の放電動作電圧 $\mathrm{V}_{\mathrm{Ar}}$ の前後 の值となる場合には, 前段増幅器の内部のインピーダンス $\mathrm{Z}_{\mathrm{BR}}$ を需要家の数だけではなくサージも考慮して設定し直 し, 次段の増幅器に加わる過電圧を $\mathrm{V}_{\mathrm{Ar}}$ より小さくすること が故障低減対策の一つになると考えられる。

汎用機器の設置に際し, サージ電流值がどの程度であれ ば, 各機器に加わる過電圧がその保護特性の過電圧制限電 圧の範囲 $\mathrm{V}_{\mathrm{Ar}}$ に入るか否かなどを本論文で述べた方法で検 討でき，故障低減に効果が期待できると考える。

〈7·3〉 タップオフ TOについて 前述のように TOの 故障比率は PS に次いで大きい。TO に接続された需要家側 には保安器を設置し, 安全のための接地を施すが, 各戸で 異なる。保安器内に避雷器と低域フィルターがあり, 宅内 へのサージ侵入阻止と通信ケーブルの電力線との接触事故 による強電流阻止をはかっている。TO には図 12 に示す $\mathrm{V}_{\mathrm{c} 2}$ と殆じ同じか少し低下した対地電位がかかり, 過電圧は分 岐に依存する $\mathrm{Z}_{\mathrm{BR}}$ による低下分だけ低くなる。TO ではフェ ライトコアに巻かれた複数のコイルなどのハイブリッド結 合によって, 対地電位と過電圧が電磁的に結合されており, サージによる過電圧対策には, 対地電位の高さ, 各戸の接 地条件の差異, 複数の避雷器の特性など最も複雑な条件を 考慮することが要求される。

対策の足がかりとして，TOの接地を十分確認した上で， $\mathrm{TO}$ から各戸への引込み線側の接地された避雷器の放電動作 をチェックし, 接地及び避雷器両方の特性を含めた動作特 性を吟味することによって, 最も大きいと見られる対地電 位による障害などの対策から検討を始めることが必要と考 えられる。

\section{8. おわりに}

配電系の電柱に併設された通信用電源装置が受けるサー ジ電流による過電圧を検討した。直撃雷によるサージ電流 より小さく配電系では特に問題ないと考えられているが発 生頻度の高い避雷器の放電や続流によるサージ電流が配電 系の接地点と通信用電源装置の接地点に流れた場合, その 電位の上昇が, 通信系の諸機器に大きな過電圧を生ずるメ カニズムを回路モデルと過渡解析により明らかにした。

次いで, 得られた結果をもとにフィールド調査で得られ た故障データの説明と検討を行った。さらに, 通信システ ム系の機器にかかる過電圧の影響とこれに依存して決まる 保護特性について考察し, この様な検討に本論文の過電圧 の評価手法が有効であることを示した。

本論文でとりあげた通信システムのモデル化による過電 圧の検討は, 接地データや使用システム条件などの外的条 件と各機器の具体的な保護対策内容をつめることにより検 討効果を一層高められると考える。

謝 辞

ご指導ご鞭撻をいただいた関係各位に感謝を致します。

(平成 19 年 9 月 3 日受付, 平成 20 年 2 月 27 日再受付) 


\section{文献}

(1) M. Aizawa, M. Watabe, and K. Ito : "Field Report of Reliability in CATV System", Cmmunication Study Committee of IEE Japan, CMN-91-25, (1991-3) (in Japanese)

藍澤 實・渡部基雄・伊東勝二：「CATV の信頼度調查結果」，電気 学会通信研究会, CMN-91-25 (1991-3)

(2) Subcommittee for Power Distribution Systems,Lightning Protection Design Committee : "Guide of Lightning Protection Design for Power Distribution Lines", CRIEPI, p.10, Fig. 2.3.1, Curve[1] (2002-2) (in Japanese)

耐雷設計委員会, 配電分科会: 「配電線耐雷設計ガイド, 総合報告 T69」, 財団法人電力中央研究所, p.10, Fig. 2.3.1 推奨曲線[1] (2002-2)

(3) J. Masuda : "Arrester and its Application to Field Use", IEEJ, pp.57-60, p.150 (1968-8) (in Japanese) 益田淳一: 「避雷器とその適用」, 電気学会, pp.57-60, p.150 (1968-8)

(4) IEC60060-1, Impulse current $8 \times 20 \mu \mathrm{s}, 10 \times 350 \mu \mathrm{s}$, and others are suggested; IEEJ "Electrical Technology Handbook revised ed.", p.512 (1988-2) (in Japanese)

国際電気標準会議 IEC60060- 1 には $8 \times 20 \mu \mathrm{s}, 10 \times 350 \mu \mathrm{s}$ 等が提示され ている。電気学会の電気工学ハンドブック改定版 p. 512 には前記の 8 $\times 20 \mu \mathrm{s}$ 記されている。(1988-2)

(5) IEEJ, Technical Committee : "Discharge Current of Arresters", \#33, (1959-7) (in Japanese)

電気学会: 「電気学会技術報告第 33 号避雷器放電電流」, p.8 (1959-7)

(6) IEEJ, Electrical Engineer's Handbook (1988-2) (in Japanese)

電気学会 : 「電気工学ハンドブック」, 機器の試験電圧, p.498 (1988-2)

( 7 ) T. Noda, H. Honda, A. Asakawa, T. Shindo, and Yokoyama : "A Pole-Mounted Transformer Model for the Assessment of Transferred Lightning Surges from a Distribution Line to a ConsumerEntrans", CIGRE 2006, CA-103

(8) H. Motoyama : "Experimental Study in Transient Characteristics of Earth Resistance Experienced in Field Electrodes", CRIEPI, ReportH04010 (2005-5) (in Japanese)

本山英器 : 「各種接地電極の過渡接地抵抗特性の実験的検討」, 電力 中央研究所報告 : 研究報告, H04010 (2005-5)

(9) J. Hällström, S. Berlijin, et al. : "Applicability of different implementations of K-factor filtering schemes for the rivision of IEC60060-1 and 2", Proc. of the X IVth International Symposium on High Voltage Engineerig,Aug. 25-29 (2005)

(10) K. Ohashi, et al. : "Electrical Transmission Technology", IEEJ p.100, p.105 (1967-4) (in Japanese) 大橋 喬, 他: 「送電工学 (改定版)」, 電気学会, p.100, p.105 (1967-4)

(11) C. Yamada, M. Katsurai : "Electromagnetics", IEEJ, pp.282-283 (2005-8) (in Japanese)

山田直平・桂井＼cjkstart誠：「電気磁気学」, 電気学会, pp.282-283 (2005-8)

付

録

1. インダクタンス $\mathrm{L}$ の評価

次の 3 つの式を用いた。

直線状単線の場合 : $\mathrm{L}=\mu \mathrm{o} \times 1 \mathrm{x} /(2 \pi) \cdot(\ln (2 \times 1 \mathrm{x} / \mathrm{a})-1)$.

$[\mathrm{H}], \mu \mathrm{o}=4 \pi \times 10^{-7} \mathrm{H} / \mathrm{m}, \mathrm{lx}$ : 線路長 $\mathrm{m}, \mathrm{a}$ : 導体半径 $\mathrm{m}_{\circ}$

(電気磁気学, 第 2 改定, p.277, 電気学会)

大地が零電位面の場合（往復導線状）: $\mathrm{L}=\mu \mathrm{o} / \pi \times$

$(\ln (\mathrm{D}-\mathrm{a}) / \mathrm{a}) \cdot[\mathrm{H} / \mathrm{m}], \mathrm{D}$ : 導体間 $\mathrm{m}_{\circ}$

（基礎電磁気学，p.158-159，電気学会，両導体間 D で,

D/2 を地表とし, D の代わり正確な D-a とし, 電流は導体

表面とする。）

相当大地面の深さ $\mathrm{He}$ が $300 \mathrm{~m}$ の場合：

$\mathrm{Le}=\mathrm{L}_{11}+\mathrm{Lg}, \mathrm{L}_{11}=(1 / 2+2 \times \ln (2 \mathrm{He} / \mathrm{a})) \times 10^{-7} .[\mathrm{H} / \mathrm{m}]$,

$\mathrm{Lg}=1 / 2 \times 10^{-7}$. [H/m], $\mathrm{He}=300 \mathrm{~m}$ 。

（送電工学，改定版, p.100, 電気学会)

伊 東 勝二 (正員) 1942 年 2 月 15 日生。 1966 年 3 月横

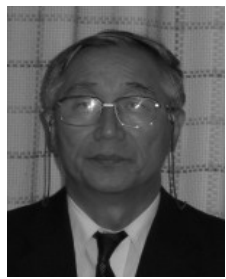
浜国立大学工学部電気工学科卒業。1968 年 3 月横浜国立大学大学院修士課程修了。同年 4 月 古河電気工業（株）入社。電力事業部の設計技 術部門配電開発関係に従事, その後, 情報通信 事業部の電力システム開発・電力通信関係，さ らに, 光システム部門に従事など, 現在に至る。

廣 瀬 靖 雄

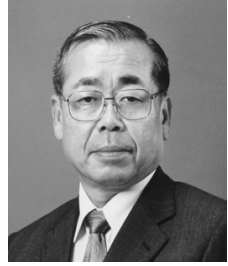

（正員） 1943 年 8 月 11 日生。1966 年 3 月横 浜国立大学工学部電気工学科卒業。1968 年 3 月同大学大学院修士課程修了。同年同大学工学 部電気工学科助手。1973 年イリノイ州立大学大 学院博士課程修了。横浜国立大学工学部電気工 学科講師を経て 1977 年同大学助教授。現在, 横浜国立大学大学院工学研究院教授。主として レーザの計測への応用, 電子回路, 光エレクト ロニクスなどに関する研究に従事。Ph.D.。電子 情報通信学会, IEEE 各会員。 